\title{
HUBUNGAN KEPADATAN DAN KESESAKAN DENGAN STRES DAN INTENSI PROSOSIAL PADA REMAJA DI PEMUKIMAN PADAT
}

\author{
Lilih Cholidah \\ Djamaludin Ancok \\ Haryanto

\begin{abstract}
Penelitian ini bertujuan untuk melihat adanya hubungan antara kepadatan dan kesesakan dengan stres dan intensi prososial pada remaja di pemukiman padar. Sebagai variabel bebas adalah kepadatan jumiah penghuni dan kesesakan sedangkan sebagai variabei tergantung adaiah stros dan intensi prososlal. Hipotesis dalam penelitian ini adalah: (1) Ada hubungan positif antara kepadat an dan kesesakan dengan stres; (2) Ada hubungan negatif antara kepadatan dan kesesakan dengan intensi prososial. Subjek penelitian adalah 80 remaja penghuni pemukiman di Keluriahan Duri Utara, Kecamatan Tambora, Jakarta Barat. Penelitian ini menggunakan analisis korelasi regresi ganda (multiple regression). Hasil analisis menunjukkan bahwa (t) ada hubungan positif antara kepadatan dan kesesakan dengan stres pada remaja, kepadatan dan kesesakan memberikan sumbangan secara bersama-sama terhadap stres sebesar 17 persen, (2) tidak ada hubungan antara kepadatan dan kesesakan dengan intensi prososial pada remaja.
\end{abstract}

Ulih Cholidah, S.Psi, adalah alumnus Fakultas Psikologi UGM.

Dr. H. Djamaludin Ancok, lahir di Bangka pada 18 Agustus 1946 , adalah dosen Fakultas Psikologi UGM dan Dekan Fakultas Psikologi UIt. Menulis buku "Psikologi islami" dan "Nuansa Psikologi Pembangunan". Banyak melakukan penelitian dan terlibat dalam berbagai pertemuan ilmah intemasional.

Drs. Haryanto, MS, adalah dosen Fakultas Psikologi UGM. Akti memberikan ceramah dengan tema religiusitas dan pendidikan anak. Juga pendiri dan pengu-rus Yayasan Insan Kamil Yogya
D embangunan jangka panjang tahap ke dua (P.JPT II) menekankan pada pentingnya peningkatan kualitas sumber daya manusia Indonesia. Kualitas sumber daya manusia ini sangat perlu untuk menunjang keberhasilan pembangunan nasional yang lancar dan berkesinambungan.

Bagi pemerintah, peningkatan kualitas sumber daya manusia ini merupakan tantangan yang cukup berat, karena kurva pertambahan penduduk Indonesia semakin mengindikasikan kecenderungan kenaikan yang pesat dari tahun ke tahun. Hasil sensus tahun 1990 menunjukkan bahwa penduduk Indonesia berjumlah 179,4 juta jiwa dan meningkat sebesar 1,98 persen per tahun (BPS, 1991).

Selain faktor pertumbuhan penduduk yang cukup tinggi, tantangan lain bagi pe- 
merintah Indonesia adalah naiknya arus urbanisasi ke kota-kota besar. Sebagaimana yang terjadi di negara berkembang lain d dunia ini, uranisasi ini disebabkan oleh belum cukup meratanya industrialisasi, modernisasi dan pembangunan. Arus urbanisasi ini terpusat ke kota-kota besar tertentu, seperti Jakarta, Surabaya, dan Medan. Kalau pada tahun 1980 daerah kota menampung sekitar 22,4 persen penduduk, ternyata pada tahun 1990 membengkak menjadi 30,9 persen (BPS, 1993).

Pertambahan penduduk yang eksplosif dan lajunya arus urbanisasi ini jelas merupakan beban bagi perkotaan. Salah satu masalah yang timbul adalah masalah penyediaan pemukiman bagi penduduk, karena kebutuhan akan pemukiman sudah merupakan kebutuhan masyarakat di samping sandang dan pangan. Pada waktu penduduk kota belum begitu banyak, masalah kebutuhan akan tempat tinggal bukanlah masalah yang merisaukan, karena penduduk masih dapat membangun tempat tinggalnya dengan leluasa. Akan tetapi pertambahan penduduk dan keterbatasan lahan untuk pemukiman di kota menimbulkan daerah pernukiman yang semakin padat. Dalam tinjauan psikologi lingkungan, maka pemukiman penduduk perkotaan pada urnumnya mempunyai dua ciri yaitu, kepadatan (density) dan kesesakan (crowding) yang tinggi.

Kondisi ini diperburuk oleh kecenderungan selama ini yang memandang pernbangunan pemukiman hanya dalam bentuk pembangunan fisik saja sehingga kurang memperhatikan faktor-faktor psikologis yang mungkin terjadi di dalamnya. Demikian pula pembangunan sosial hanya dterjemahkan dalam pembangunan lingkungan fisik, seperti sarana olahraga, sarana rekreasi, dan lain-lain. Padahal pembangunan sosial seharusnya lebih diterjemahkan dengan fokus kehidupan bersama yang menghasilkan pola interaksi sosial antar individu dan kelompok secara adekuat. Dalam pandangan ini arti dari peningkatan kualitas sumber daya manusia ma- syarakat Indonesia meniadi nampak jelas. Proporsi luas tanah untuk rumah tempat tinggal penduduk kota yang semakin sempit menyebabkan kepadatan yang tinggi dan ruang untuk keperluan-keperluan individu dan kelompok juga semakin menyempit. Menurut Hotahan (1982), kepadatan (density) adalah sejumlah individu pada setiap ruang atau wilayah. Altman (1975) membagi kepadatan menjadi kepadatan dalam dan kepadatan luar. Kepadatan dakam berarti jurniah manusia dalam suatu ruangan sedangkan kepadatan Iuar berarti jumlah orang atau pemukiman di suatu witayah. Dalam hubungannya dengan kondisi psikologis penghunian rumah, kiranya apa yang dikatakan oleh Holahan dan definisi kepadatan dalam dari Altman lebih bisa diterapkan, di mana dalam setiap unit rumah dihuni oleh sejumlah orang. Apalagi dalam masyarakat Indonesia sering dijumpai adanya rumah yang dihuni oleh jumlah anggota keluarga yang relatif besar, yaitu selain keluarga inti yang terdiri dari ayah, ibu, dan anak, terkadang masih ditambah dengan sanak keluarga sedarah lainnya.

Rumah merupakan lingkungan yang paling dekat dan penting bagi manusia karena harnpir setengah dari hidupnya dihabiskan di rumah. Setelah penat bekeria seharian, manusia melepas lelah dan beristirahat di rumah, baik istirahat di siang hari maupun tidur lelap of malam hari (Awaldi, 1990). Rumah sebagai lingkungan tempat tinggal digunakan untuk bermacam-macam kegiatan, seperti membaca, menerima ta $\mathrm{mu}$, berkumpul dengan keluarga, serta menyiapkan strategi dan rencana kerja untuk esok hari.

Parwati (dalam Budiharjo, 1984) mengatakan bahwa fungsi rumah bagi orang hidup semakin penting, of samping tempat berlindung, rumah juga berfungsi sebagai tempat berlangsungnya proses sosialisasi, yaitu proses di mana seorang individu diperkenalkan kepada nilai-nilai, adat kebiasaan, yang berlaku dalam masyarakat juga rumah berfungsi sebagai tempat untuk 
memenuhi kebutuhan-kebutuhan hidup seseorang seperti kebutuhan bergaul, kebutuhan rasa aman, dan kebutuhan untuk mengaktualisasikan diri, serta rumah juga sebagai wahana untuk mengasuh anak hingga dewasa.

Mengingat pentingnya fungsi rumah, sebaiknya rumah dapat dirasakan sebagai suatu lingkungan psikologis yang dapat memberikan rasa aman dan nyaman bagi penghuninya dan perlu dihindarkan rumah yang terlalu sempit. Penyempitan ruang individual dalam rumah akan menimbulkan berbagai macam permasalahan psikologis yang serius. Suasana tidak nyaman tersebut disebabkan oleh banyaknya anggota keluarga yang menempati rumah tersebut, banyaknya orang yang berlalu lalang d sekitar rumah, dan jarak antar rumah yang sangat dekat, serta suara bising yang mengganggu terus menerus. Kondisi ini jelas akan merugikan perkembangan psikologis anggota keluarga, terutama pada anak-anak dan remaja.

Selain masalah kepadatan, ciri kedua dari pemuklman kota adalah kesesakan. Pengertian kesesakan (crowding) adalah perasaan subjektif individu terhadap keterbatasan ruang yang ada (Holahan, 1982) atau perasaan subjektif karena terlalu banyak orang lain d sekelilingnya (Gifford, 1987). Kesesakan muncul apabila individu berada dalam posiși terkungkung akibat persepsi subjektif keterbatasan ruang, karena dibatasi oleh sistem konstruksi bangunan rumah dan tertalu banyaknya orang lain di sekelilingnya. Hal ini menyem babkan banyak stimulus yang tidak diinginkan dapat mengurangi kebebasan masingmasing individu, serta interaksi antar individu semakin sering ter jadi, tidak terkendali, dan informasi yang diterima sulit dicerna.

Kondisi padat dan sesak dapat menimbulkan berbagai permasalahan psikologis yang serius. Kepadatan di dalam rumah dan sekitar rumah menyebabkan keterbatasan sumber-sumber yang bernilai bagi individu dan selanjutnya akan menghambat tingkah laku untuk mencapai tujuan.
Dalam suasana padat dan sesak kondisi psikologis yang negatif mudah timbul yang merupakan faktor penunjang yang kuat untuk munculnya stres dan bermacam aktivitas sosial negatif (Wrightsman dan Deaux, 1981). Bentuk aktivitas sosial negatif yang dapat diakibatkan oleh suasana padat dan sesak antara lain:

Pertama, munculnya bermacam-macam penyakit baik fisik maupun psikis, seperti stres, tekanan darah meningkat, psikosomatis, dan gangguan jiwa.

Kedva, munculnya patologi sosial, seperti kejahatan dan kenakalan remaja.

Ketiga, muncuinya tingkah laku sosial yang negatif, seperti agresi, menarik diri, berkurangnya tingkah laku menolong (prososial), dan kecenderungan berprasangka.

Keempat, menurunnya prestasi kerja dan suasana hati yang cenderung murung (Holahan, 1982).

Menurut Baum dkk (dalam Evans, 1982), peristiwa atau tekanan yang berasal dari lingkungan yang mengancam keberadaan individu dapat menyebabkan stres. Bila individu tidak dapat menyesuaikan dengan keadaan lingkungannya, maka akan merasa tertekan dan terganggu dalam berinteraksi dangan lingkungan, dan kebebasan individu merasa terancam sehingga mudah mengalami stres.

Kawasan padat dan sesak selain dapat menimbulkan stres juga menyebabkan individu lebih selektif dalam berhubungan dengan orang lain, terutama dengan orang yang tidak begitu dikenalnya. Tindakan ini dilakukan individu untuk mengurangi stimuli yang tidak diinginkan yang dapat mengurangi kebebasan individu. Tindakan selektif ini memungkinkan menurunnya keinginan seseorang untuk membantu orang lain (intensi prososial). Perilaku prososial adalah perilaku seseorang yang ditujukan pada orang lain dan memberikan keuntungan fisik maupun psikologis bagi yang dikenakan tindakan tarsebut. Perilaku prososial mencakup tindakan-tindakan kerja sama, membagi, menolong, kejujuran, dermawan serta mempertimbangkan kesejahteraan 
orang lain (Mussen dkk, 1979).

Perilaku prososial sangat penting artinya bagi kesiapan seseorang dalam mengarungi kehidupan sosialnya. Karena dengan kemampuan prososial ini seseorang akan lebih diterima dalam pergaulan dan akan dirasakan berarti kehadirannya bagi orang lain.

Para ahli umumnya berpendapat bahwa perkembangan kemampuan sosial seseorang terjadi pada masa remaja. Pada masa ini individu banyak melakukan kegiatan-Kegiatan terutama bersama kelompok dan lingkungannya, sehingga mereka mendapat kesempatan untuk melatih kemampuan sosialnya. Remaja sebagai mahluk sosial membutuhkan orang lain sebagai kawan hidup. Remaja memerlukan kelompok sosial tempat ia mengidentifikasi diri, berinteraksi dengan keluarga, kawan, dan orang lain. Di dalam proses perkembangannya remaja dipengaruhi pula oleh lingkungan dan budaya setempa! (Nuryoto, 1993).

Remaja akan selalu menerima nilai-nilai dan norma-norma dari lingkungan dan masyarakat, yang semuanya akan diintemalisasi menjadi norma-norma dan nilai-nilai bagi dirinya. Nilai-nilai dan norma-norma yang telah dinternalisasi dalam diri individu inilah yang kemudian menentukan dirinya menjadi orang yang prososial atau tidak.

Kondisi lingkungan dan tempat tinggal yang pad at dan sesak juga mengakibatkan banyaknya stimulus dari luaryang masuk, seperti suasana yang ramai, bising, tidak leluasa bergerak sehingga dapat mengakibatkan remaja berusaha mengurangi kontak sosial dengan orang d sekitamya, yang akhirnya akan menurunkan intensi prososialnya.

Di samping remaja sebagai mahluk sosial, mereka jug a adalah mahluk individual, yang memiliki kebutuhan-kebutuhan tertentu yang kadang berbeda dengan kebutuhan kelompok sosial tempat ia melakukan interaksi sehari-hari. Remaja kadang memerlukan waktu untuk menyendiri, memisahkan diri dari orang lain untuk melakukan kegiatan atau kebutuhan pribadi, atau biasa disebut privasi. Privasi ini membutuhkan suasana lingkungan yang tidak terlalu padat dan sesak. Bila lingkungan terlalu padat dan tidak memberikan kondisi dan situasi yang baik maka kebutuhan psikologis remaja akan terganggu dan memungkinkan munculnya perilaku patoogi sosial ataupun stres.

\section{HIPOTESIS}

Pertama, ada hubungan positif antara kepadatan dan kesesakan dengan stres pada remaja di pemukiman padat. Semakin tinggi kepadatan dan kesesakan maka semakin tinggi stres yang dialami.

Pertama, ada hubungan negatif antara kepadatan dan kesesakan dengan intensi prososial pada remaja di pemukiman padat. Semakin tinggi kepadatan dan kesesakan maka intensi prososial semakin rendah.

\section{METODE PENELITIAN}

Subjek yang digunakan dalam penelitian ini adalah remaja yang bertempat tinggal di Kelurahan Duri Utara Jakarta Ba rat Mereka terdiri dari 80 orang, yang terdiri dari pria dan wanita yang berusia antara 17 sampai 22 tahun, berstatus belum menikah.

Sementara alat pengumpul data yang digunakan dalam penelitian ini adalah seba. gai berikut:

Data Kepadatan. Data kepadatan diperoleh melalui perbandingan luas bangunan rumah tinggal dengan jumlah penghuri dalam satu unit rumah tinggal masingmasing subjek penelitian.

Skala Kesesakan. Skala kesesakan disusun berdasarkan konsep kesesakan yang dikemukakan oleh Schmidt dan Keating (1979). Skala ini terdiri dari 54 aitem berupa pernyataan-pernyataan dengan empat alternatif jawaban, yaitu sangat sesuai, sesuai, tidak sesuai, sangat tidak sesuai. Aitem-aitern di atas memiliki koefisien validitas bergerak dari 0,201 sampai 0,781 dan koefisien reliabilitas sebesar 
0,947 sehingga layak digunakan sebagai alat pengumpul data.

Skala Stres. Skala stres disusun berdasarkan teori yang dikemukakan oleh Crider dkk (1983). Skala ini terdiri dari 39 aitem berupa penyataan-pemyataan dengan empat altematif ja waban, yaitu sangat sesuai, sesuai, tidak sesual, sangat tidak sesuai. Aitem-aitem ditas memiliki koefisien validitas bergerak dari 0,191 sampai 0,669 dan koefisien refiabilitas sebesar 0,913 sehingga layak digunakan sebagai alat pengumpul data.

Skala Intensi prososial. Skala intensi prososial ini disusun berdasarkan bentukbentuk tindakan prososial yang dikemukakan oleh Mussen dkk (1979). Skala ini terdiri dari 30 aitem berupa pernyataan-pernyataan dengan tiga alternatif jawaban yang telah diukur bobot intensinya sehingga dalam tiap aitem, subjek mempunyai kemungkinan untuk mendapat sekor satu, dua, dan tiga, Aitem-aitem di atas memiliki koefisien validitas bergerak dari 0,218 sampai 0,682 dan koefisien reliabilitas sebesar 0,875 sehingga layak digunakan sebagai alat pengumpul data.

Untuk menguji hipotesis penelitian digunakan teknik analisis regresi ganda (multiple regression) dengan menggunakan fasilitas program SPSS/PC+ versi 3.1.

\section{HASIL ANALISIS DATA}

Hasil perhitungan analisis regresi ganda menunjukkan:

Pertama, ada hubungan positif yang signifikan antara kepadatan dan kesesakan dengan stres pada remaja of pemukiman padat $(F=9,12577 p<0,01)$. Kepadatan dan kesesakan memberikan sumbangan secala bersama-sama terhadap stres sebesar 17 persen ( $R$ square $=0,17243$ ). Jadi hipotesis pertama yang diajukan dapat diterima.

Kedua tidak ada hubungan antara kepadatan dan kesesakan dengan intensi prososial pada remaja di pemukiman padat $(F=0,09242 p>0,05)$. Jadi hipotesis kedua yang diajukan bahwa ada hubungan ne- gatif antara kepadatan dan kesesakan dengan intensi prososial pada remaja di pemukiman padat ditolak.

\section{PEMBAHASAN}

Setelah analisis dilakukan dengan menggunakan regresi ganda (multiple regriess'on), ternyata hasil perhitungan statistik untuk menguji hipotesis pertama menunjukkan bahwa secara um um kepadatan dan kesesakan mampu memprediksi stres subjek penelitian. Koefisien determinasi sebesar 0,17243 menunjukkan bahwa kepadatan dan kesesakan memberikan sumbangan secara bersama-sama terhadap stres subjek penelitian sebesar $17,243 \%$. Apabila dilihat secara khusus terlihat bahwa variabel kesesakan lebih berperan terhadap stres subjek penelitian daripada variabel kepadatan.

Penjelasan yang dapat diberikan berkaitan diterimanya hipotesis pertama yang menyatakan ada hubungan positif antara kepadatan dan kesesakan dengan stres ini sesuai dengan pendapat yang dikemukakan oleh Baum dkk (dalam Evans, 1984) dan Jain (1987). Mereka berpendapat bahwa stres mudah dialami individu yang mengalami keterbatasan ruang dan kesesakan setiap hari, karena kepadatan dan kesesakan lebih banyak mengakibatkan stres yang berhubungan dengan responrespon psikis individu.

Dalam penelitian ini tingkat kesesakan yang dialami subjek menunjukkan kategori rendah dengan rerata 131,95 , dan tingkat stres d atas rata-rata, dengan rerata 99,94 . Meskipun tingkat kesesakannya rendah, terdapatnya korelasi yang signifikan akan menjelaskan terjadinya peningkatan stres apabila tingkat kesesakan bertambah. Tingkat kesesakan yang termasuk kategori rendah menunjukkan bahwa subjek memiliki persepsi yang mampu dikontrolnya. Kesesakan akan terjadi apabila individu gagal mencapai privasinya, yaitu jika privasi yang diperoleh tidak sesuai dengan privasi yang diinginkan. Apabila privasi masih bisa 
dicapai maka individu tidak akan merasa sesak (Altman, 1975).

Kecilnya peranan variabel kepadatan dalam memprediksi stres disebabkan subjek penelitian sudah terbiasa dengan keadaan lingkungan yang padat dan rumah yang relatif sempit. Bell dkk (1978) mengatakan bahwa semakin sering atau konstan suatu stimulus muncul, maka akan timbul pembiasaan yang bersifat psikologis (adaptasi) dan fisik (habituasi). Mekanisme adaptasi merupakan mekanisme yang dimiliki individu untuk mengatasi permasalahannya, sehingga di dalam keadaan yang sulit dihindari, individu cenderung beradaptasi dengan lingkungan. Pada kondisi yang kurang layak, seperti kondisi padat, maka mekanisme adaptasi akan menjadi salah satu pilihan perilakunya, sedangkan kemampuan untuk pindah dari lingkungan tersebut tidak mungkin atau kecil kemungkinan untuk dilakukan.

Selain itu subjek penelitian dimungkinkan juga mempersepsi kepadatan menjadi positif. Walaupun subjek tinggal di tempat yang padat mereka tetap merasa senang. hal ini dimungkinkan mereka masih dapat memenuhi kebutuhannya. Teori Intensitas Kepadatan (Densily intensity Theory) yang dikemukakan oleh Freedman (1975) mengatakan bahwa situasi padat akan memperbesar reaksi individu terhadap stimulus yang dihadapinya. Individu yang mempunyai persepsi positif terhadap stimulus maka dalam situasi pad at stimulus tersebut akan dipersepsi menjadi menyenangkan bagi dirinya dan sebaliknya bila stimulus tersebut dipersepsi sebagai suatu yang negatif maka dalam situasi padat stimulus tersebut menjadi aversif bagi individu yang bersangkutan. Kehadiran orang lain atau keterbatasan ruang tidak akan menjadikan dirinya terganggu tetapi justru diharapkan karena merupakan sarana untuk memenuhi kebutuhannya.

Kecilnya peranan variabel kepadatan terhadap stres juga diperkirakan adanya ruang-ruang terbuka di sekitar rumah dan lingkungan tempat subjek penelitian. Apa- lagi remaja yang lebih banyak melakukan aktivitas, bergaul dengan teman sebayanya, mereka sering meninggalkan atau keluar dari rumah dan mencari tempat-tempat yang lebih leluasa. Teori Setting Sysrem yang dikemukakan oleh Rapoport (daIarn Haryadi, 1989) mengemukakan bahwa setiap perilaku manusia dalam lingkungan membutuhkan wadah atau tempat perilaku itu dilakukan. Apabila wadah-wadah dalam lingkungan sudah tidak mampu lagi memenuhi tuntutan perilaku yang muncul, maka manusia akan mencari wadah-wadah lain yang ada di lingkungannya. Dalam situasi padat dalam rumah, subjek berusaha mencari tempat lain untuk memenuhi tuntutan perilakunya. Hal yang biasa dilakukan subjek adalah dengan memanfaatkan adanya ruang-ruang terbuka um um seperti adanya pusat perbelanjaan di sekitar pemukiman. warung-warung dan lain-lain yang dipakai untuk berkumpul antara penghuni-penghuni sehingga mereka dapal keluar dari rumah yang padat. Di sekitar lokasi penelitian ini terdapat banyak pusat-pusat perbelanjaan seperti pusat perbelanjaan Roxy atau Mal Citraland. Tempat-tempat ini oleh remaja di lokasi penelitian dapat dijadikan salah satu jalan keluar dari lingkungan atau kondisi pemukiman yang pad at dan sesak. walau d sana mereka hanya berjalan-jalan atau berkumpur dengan teman-temannya.

Selain itu juga subjek penelitian, dalam hal ini remaja, sebagian besar dari mereka adalah masih bersekolah, maka sebagian besar pula waktu mereka lebih banyak dihabiskan di sekolah dan di luar rumah daripada di dalam rumah sehingga kondisi rumah yang padat tidak begitu mempengaruhi aktivitas mereka.

Hipotesis kedua yang menyatakan bahwa ada hubungan negatif antara kepadatan dan kesesakan dengan intensi prososial pada remaja di pemukiman padat tidak terbukti. Hal ini dapal disebabkan oleh pengaruh berbagai macam faktor.

Kehidupan sosial di daerah pemukiman padat biasanya menunjukkan adanya ikatan sosial yang erat. Munculnya hu- 
bungan sosial yang erat di daerah pemukiman padat ini dipengaruhi oleh keakraban (propiquity) yang antara tain ditentukan oleh desain arsitektural, dan homogenitas masyarakatnya (Proshansky dkk, 1976). Keakraban ini disebabkan oleh adanya larak rumah yang satu dengan yang lain sangat berdekatan secara horisontal dan saling berhadapan, sehingga memungklnkan adanya kontak visual dan kontak sosial yang lebih tinggi. Hubungan sosial ini akan intensil dengan adanya homogenitas latar belakang masyarakat baik tatar belakang sosial ekonomi, usia, pendidikan, pekerjaan, nilai maupun minat.

Ikatan sosial dan ketetanggaan yang erat di pemukiman padat ini memungkinkan munculnya perilaku prososiak di antara penghuninya. Sesuai dengan pernyataan Staub (1978) bahwa kondisi fisik yang berdekatan (proximity) memberikan sumbangan dalam perkembangan untuk saling berkunjung, berkomunikasi, berbagi, serta mempedulikan orang lain.

Teori Gemeinschaftyang dikemukakan oleh Tonnies (dalam Soekanto, 1982) menyebutkan bahwa kehidupan dalam keluarga, kekerabatan, rukun tetangga dipengaruhi adanya gemeincshaft of place, yaitu kehidupan bersama di mana anggota-anggotanya dikkat ofeh hubungan batin yang murni dan bersifat alamiah yang terdiri dari orang-orang yang berdekatan tempat tinggal, sehingga kehidupan antar anggota saling menolong.

Selain itu tingginya intensi prososial remaja o pemukiman padat ini juga dapat dikaitkan dengan faktor kebudayaan. Di dalam masyarakat Indonesia, ambang batas toleransi terhadap kepadatan dan kesesakan ternyata tinggi. Hal ini dapat dilihat dalam kehidupan sehari-hari di angkutan umum, jatan raya, orang masih tersenyum dan mengalah di tengah situasi padat, sehingga bisa dikatakan manusia dan budaya iuga mempengaruhi persepsi terhadap kopadatan (Singarimbun, 1992). Selain itu budaya tolong menolong dan gotong royong antar sesama dalam kehidupan se- hari-hari telah terbiasa dilakukan sejak individu masih kecil, yang merupakan hasil bolajar dari orangtua dan lingkungan mereka. Sikap saling menolong dan gotong royong yang diajarkan oleh masyarakat dan orangtua ini dinternalisasi dalam diri individu menjadi norma-norma dan nilai-nilai bagi dirinya sehingga indivldu menjadi orang yang prososial.

Faktor yang juga diduga mempengaruhi tingginya intensi prososial subjek dalam hal ini remaja di pemukiman padat adalah faktor sosialisasi remaja tersebut terutama ke dalam kelompok teman sebaya. Pada masa remaja orientasi sosial individu beralih dari lingkungan keluarga, khususnya orangtua, kepada kelompok teman sebaya, sehingga peranan teman sebaya menjadi tebih lobih penting dalam membentuk pola-pola perilaku dewasa dan sosiainya (Hurlock, 1973; Mönks dkk, 1988). Kecenderungan remaja selalu berkumpul, berkelompok, dan melakukan aktivitas bersama dengan teman sebaya ini menjadikan remaja sering berada di luar rumah, sehingga kondisi rumah yang padat dan sesak tidak mempengaruhi peritaku sosial remaja tersebut. Seringnya remaja berkumpul dan bergaul dengan teman sebayanya menjadikan mereka mempunyai tingkat solidaritas yang tinggi antar sesamanya dan saling menolong, sehingga kondisi rumah dan lingkungan yang padat dan sesak tidak menurunkan intensi prososial remaja tersebut.

Tingginya intensi prososial remaja di pemukiman padat menunjukkan bahwa teori dari Barat belum tentu dapat diterapkan di Indonesia. Hal ini disebabkan adanya perbedaan budaya. Masyarakat Barat biasanya lebih mementingkan faktor individual sedangkan masyarakat Indonesia sebagai masyarakat Timur tebih mementingkan faktor kolektif atau kebersamaan, gotong royong antar sesama. To (dalam Agustini, 1994) menyebutkan bahwa orang Timur dilatih dan dididik untuk menjadi bijaksana, mengetahui proporsi yang tepat dalam merasa, berpikir, dan bertindak. 
Rasa harmoni yang merupakan ciri masyarakal Timur menuntul mereka untuk ramah, baik hati, menghargai dan menanggung perasaan orang lain, mereka ingin hidup akrab bersama kelurarga, kenalan, dan telangga serta selalu menjaga hubungan baik itu.

\section{KESIMPULAN DAN SARAN}

Dari hasil analisis data diperoieh kesimpulan bahwa hipolesis pertama yang menyatakan adanya hubungan antara kepadatan dan kesesakan dengan stres pada remaja di pemukiman padat dapat diterima. Dilerimanya hipotesis pertama berarti ada hubungan yang sangat signifikan antara kepadatan dan kesesakan dengan stres pada remaja di pemukiman padat.

Bila dilihat pengaruh masing-masing variabel bebas yaitu kepadatan dan kesesakan terhadap variabel tergantung yaitu stres, maka terlihat kesesakan lebih berpengaruh terhadap stres daripada kepadatan terhadap stres.

Hipolesis kedua yang menyalakan ada hubungan antara kepadalan dan kesesakan dengan intensi prososial pada remaja d pemukjman padat tidak terbukti. Hai ini berarti tidak ada hubungan antara kepadatan dan kesesakan dengan intensi prososial pada remaja di pemukiman padal. Rerata empirik intensi prososial $(74,01)$ lebih tinggi daripada rerata hipotetiknya $(45,00)$.

Untuk instansi terkait penulis mengajukan beberapa saran sebagai berikut:

Mengingat lahan pemukiman yang semakin sempit dan kurang tertata dengan baik maka perlu diadakan pembinaan proyek pengembangan kamp ung supaya lebih teratur dengan penataan yang lebih baik dan memperhatikan masalah-masalah psikologis penghuninya seperti ketentraman dan kenyamanan serta memperhatikan sarana-sarana umum seperti menyediakan fasilitas-fasilitas umum yang baik. Contoh adanya ruangan-ruangan terbuka, taman, lapangan bermain dan lain-lain.
Bagi peneliti berikutnya yang memilik minat terhadap permasalahan serupa, ada beberpa hal yang perlu diperhatikan, antara lain

Pertama, penelitian ini memiliki kelerbatasan karena hanya dilakukan di satu lokasi pemukiman padat saja, maka disarankan untuk melakukan penelitian sejenis ini di beberapa lokasi lagi. Hal ini dirasa perlu sebab karakteristik pemukiman padat sangat bervariasi sehingga tidak menutup kemungkinan bahwa hasil penelitian di lokasi lain akan menunjukkkan hasil yang agak berbeda dan juga hal Ini diperlukan untuk menghindari bias dan mendapatkan hasil yang lebih akurat.

Kedua, penelitian ini terbatas hanya pada subjek penelitian remaja saja maka disarankan untuk melakukan pada subjek penelitian yang lain seperti pada ibu rumah tangga atau ayah sehingga bisa dilihat apakah ada perbedaannya alau tidak.

Ketiga, tidak terbuktinya hipolesis kedua dimungkinkan adanya variabel-variabel lain yang dapat mencemari hasil penelitian, misalnya: tipe kepribadian mempunyai pengaruh terhadap intensi prososial seseorang. Dengan demikian untuk penelitian selanjutnya agar diperhatikan variabelvariabel yang berpengaruh dapat dikontrol.

Keempat, mengingat masih banyaknya kekurangan pada penelitian ini, disarankan untuk mempertimbangkan faktor lama tinggal, usia penghuni, jenis kelamin subjek penelitian, stalus sosial ekonomi, dan lainlain. Dengan demikian penelitian seianjutnya menjadi lebih baik. 


\section{DafTAR PUSTAKa}

Agustiri, N. 1994. Hubungan Antara Kebutuhan Berafiliasi dengan Kesesakan Psikologis pada Penaja d Rumah Su sun Pekunden Semarang. Skripsi (tidak diterbitkan). Yogyakarta: Fakultas Pskolog UGM.

Altrian L. 1975. The Environmental and Sosidi Behavor. Monterey, Califomia: Brooks/Cole Publishing Company.

Awaldt. 1990. Model Hubungan Antara Desain Lingkungan Fisik dan Rasa Aman. Skripsi(tidak ditemitkan). Yogyakarta: Fakultas Psikologi UCM.

Belt, P.A, Fisher J.D., \& Loomis, R.J. 1978. Environmenta' PSychology, Philadelpia: WB. Saunders Company.

Biro Pusat Statistk. 1991. Statistik Indonesig. Jakarta: Bro Pusat Statistik.

Biro Pusat Stalistik. 1993. Statistik Indonesia Jakarta: Bro Pusat Statistik.

Evans, G.W. 1982 . Environmental Stress Cambridge: Cambridge University Press.

Freedman, J.L. 1975. Crowding and Behavior. San Francisco: W.H. Freedman and Company-

Gitord, R. 1987 . Ervironmental Psychology. Pincoples and Practice Boston Allyn and Bacon, Inc.

Haryadi, 1989. Fesident's Strategies for Coping with Environmental Press: Relation to House-settement System in A Yogyakarta Kampung, Indonesia. Dissentation. The University of WisconsinMilwalke.

Heimstre, NW. \& McFarling. L.H. 1978. Environmental Psychology. Second Edition. California: Brooks/ Cols Pub Co.

Holahan, C.s. 1982. Erwironmental Psychology. New Yak: Pandorn House, hc.
Hurlock, B.E. 1973. AdolescentDevelopment. Tokycx MeGraw-Hill Kogakusha, Ltd.

Jain U. 1987. The Psychological Consequences of Crowding. New Deltri: Sage Publicatin india Ltd.

Mönks, F. J, Knoers, A.M.P. \& Haditono, S.R. 1988. Psikologi Porkembangan: Pengantar Dalam Berbagai Bagiannya Yogyakarta: Gadjan Mada University Press.

Mussen, P.H., Conger, J.J., Kagan, $J_{\text {., }}$ and Geiwit. J. 1979. Psychological Devalopment: A Life Span Approach. New York Haper and Rob Pub.

Nuryoto. S. 1993. Teori Porkembangan Femaja. Yogyakarta: Fakultas Psikoiogi UGM.

Parwati, E. 1984. Aspek Sosial Psikologis pada Pemukiman Masyarakat Berpenghasilan Rendiah d Kota-kota Besar. Dalam Eko Budihardio. Se jumish Masalah Pomukiman Kotr. Banding: Penerbit Alumni.

Proshansky, H.M. Ittelson, W.H. \& Rivlin, G.H $\$ 976$ Freedom of Choice and Behavior in a Physical selting. Dalam Haroid M. Proshansky, William H. Ittelson and Leanne G. Fivin (Eds). Environment tol Psychology: People and Their Physical' Set. tings. New York: Holt, Finehart and Whoton, inc.

Schmidt DE. \& Keating, J.P. 1979. Human Growding and Personal Control: An Integration of The Research. Psychological Buhletin. 86, 680 - 700 .

Singarimbun, M 1992. Fenungan dar Yogya Jakarta. Balai Pustaka.

Soekarto, S. 1982. Sosiolog Sugu Pengantar. Jakerta: CVRatawali.

Wrightsman, L.S. \& Deaux, K 1981. Socia Psychologyin The 80S. Third Edition. Monterey. Calffornia: Brooks/Cole Publishing Company. 